\title{
Literature and Society
}

\author{
Arjun Dubey \\ Head, Dept. of Applied Sciences \&Humanities Madan Mohan Malaviya Engineering College, Gorakhpur \\ U.P.India Pin Code:273010
}

\begin{abstract}
The history of literature dates back to the dawn of human civilization. The societies were formed by the human beings with objectives of fulfilling the human needs and aspirations. Setting aside which came firstthe literature or society - the aim of the author is to depict the picture of literature in society and vice versa. Both have remained inseparable from each other, for literature cannot sustain without society, and likewise the society too cannot be unnoticed in literary pieces in one way or another.
\end{abstract}

Key words: civilization, history, literature, society, values

\section{Introduction}

What is literature? What is the function of literature? What is its relation to society? Does society require literature? There are a number of such questions that hit human mind. It is through such question and answer method that the author aims at cinematographing a few aspects of literature and society.

\section{Article}

We all know that literature mirrors society. What happens in a society is reflected in literary works in one form or another. The literal meaning of literature is the art of written work in different forms, such as, poetry, plays, stories, prose, fiction etc. It may also consist of texts based on information as well as imagination.

A society is a group of people related to each other through their continuous and uninterrupted relations. It is also a group of likeminded people largely governed by their own norms and values. Human society, it is observed, is characterized by the patterns of relationship between individuals who share cultures, traditions, beliefs and values etc.

If one looks at the history of society, one will find that the nature of different societies has gone through changes from the Palaeolithic period to the present age of Information Technology. The people's living style, faiths, beliefs, cultures etc. have never remained uniformly consistent. With the passage of time, owing to changes taking place in environment and with emergence of new technologies, we observe that the societies have not remained stubborn with regards to their norms and values, the reflections of which can be found in different forms of literature. Kalidas, a great poet, ever born in Indian history, is first afraid of the uncertain attitude of the people, but then pleads his own points of views that provide us union of the old and the new. In

In Malavikamitam, his first play, the poet shows his humility and becomes uncertain whether people would accept his play. Therefore, in the beginning of the play, he pleads,

Puranamityek Nasadhu sarvam,Nachapikavayamnavmityavadyam

"Every old poem is not good because it is old; nor is every new poem to be blamed because it is new; sound critics, after critical examination, choose one or the other, the blockade must have his judgement, guided by the knowledge of his neighbours." IIn other words, everything old is not bad; nor is everything new bad. There may be something, which may not be of much use in the old, and the new may also be good. That what great men and wise people say and follow become good during all time.

In respect of literature too we notice that it has remarkably gone through changes with regard to its theme and style. The subjects of literature have been changing as they cover multiple spheres of life and society. So has been the case with the case with the language of literature also. Language is one of the tools or mediums of expressing ideas and thoughts, both in oral and written forms. Different societies have used and are still using different languages for the fulfilment of individuals 'and societies' aspirations.

Sometime it is noticed that many charges are labelled against literature as well as society. A literary writing is banned because an opposite section of society finds it mirroring beliefs and norms against that society. The examples of Salman Rushdie's The Satanic Verses and Taslima Nasrin's Lazza provide testimony to suchcharges. The paintings of Maqbul Fida Hussain were banned and burnt by a section Indian Hindu society with the charge of tarnishing their religious devotion. In the world of film industry, both in India and abroad, many films have been banned; there has been protests and demonstrations against the films for wrongly presenting the themes and using undesired language which appear hostile to the feelings of a section of society. 
Literature in a society is not only banned or attempted to be banned because of mirroring the norms and values, not found in conformity with that society, it is sometime marginalized or vehemently opposed due to another form of language it is written by and which is different from what people have been using. In the context of depicting or portraying the Epics in a language commonly used by the people during that period, examples of strong opposition by a different section of society, who not only use conventional or traditional form of language but they feel proud of it considering themselves as elite group, can be seen the world over. In India, for example, Tulsidas's Ram Charit Manas was looked down upon and disallowed by the then Pundits of Varanasi, who had been using Sanskrit as the only medium of literary and religious expression. In Europe, too, the literature written in native languages had received marginalized position in comparison to Greek and Latin until the native languages were widely used by the writers and accepted by the people after the Renaissance. Bacon's essays, first written in Latin and then re-written in English, exemplify this observation.

Another question that strikes our mind is if literature reflects only the events taking place in a society. Do the occurrences taking place in persons' lives become catalytic agent in literary creations? In India, Adi Kavi Valmiki composed his first poetry only when saw something happening which ought not to happen. It is said that he ,while taking bath and performing his religious rituals on the bank of river Tamsa, saw a female Kronch lamenting at the killing of her male partner. His heart was so much deeply overwhelmed with grief that he could not bear it and spontaneously uttered a few line lines in the form of poetry:

'maa nishhaada pratishthaamtva | magamah yat krauncha mithunaat eka | mavadhiih kaama mohitam ||' 1-2-15

shaashvatiih samaah

"Oh! Ill-fated Hunter, by which reason you have killed one male bird of the couple, when it is in its lustful passion, thereby you will get an ever-lasting reputation for ages to come"2

Here, poetry, one of the forms of literature, comes out in natural and without deliberated form immediately after the events take place in life and nature. The Poetry of Wordsworth is based on memory. He thinks of the past events and comes under the impact of past impressions with a high degree of emotions and feelings. For him, as he himself says in his Preface to Lyrical Ballads (1802) "Poetry is the spontaneous overflow of powerful feelings; it takes its origin from emotions recollected in tranquillity"3In all such and many other cases the emergence of literary creativity is followed on from the acts and events in life and nature.

However, the poet sometimes becomes so much imaginative that he thinks of the events to be followed by his literary composition, and in some cases it happens true. This is because of high level of imaginative excellence of a writer that what he thinks, though possibly unreal, is reflected in his writing. One may put charge on him saying what he has written is largely based on fancy and personal hallucination. His/her observations are more psychic than real. But as an individual he is also a part of society he lives in.

\section{Conclusion}

Thus, it appears that society acts like back up for culture and tradition of the people it reflects upon and the inhabitants of a group of society share certain similarities with regard to, assumptions, beliefs, caste, creed, myths, religion etc. Literature, when combined with culture and other facets -both abstract and concrete-of society, not only presents impalpable subjects like alienation, assimilation and transformation in society but also reflects the palpable issues, such as ,historical, political and social facts.

\section{References}

[1]. Trans by C.H.Tawney,Thacker Spink and Co.,Calcutta,1891,p.03

[2]. Valmiki Ramayan,Bala Kanda,Chapter 2

[3]. http://en.wikipedia.org/wiki/Lyrical Ballads 